\title{
Abstract not presented and not submitted for publication
}

From 9th Symposium of Experimental Rhinology and Immunology of the Nose (SERIN 2013) Leuven, Belgium. 21-23 March 2013

Published: 16 July 2013

doi:10.1186/2045-7022-3-S2-P1

Cite this article as: : Abstract not presented and not submitted for

publication. Clinical and Translational Allergy 2013 3(Suppl 2):P1.

Submit your next manuscript to BioMed Central and take full advantage of:

- Convenient online submission

- Thorough peer review

- No space constraints or color figure charges

- Immediate publication on acceptance

- Inclusion in PubMed, CAS, Scopus and Google Scholar

- Research which is freely available for redistribution

Submit your manuscript at www.biomedcentral.com/submit 